\title{
Recapitalization in an Economy with State-Owned Banks-A DSGE Framework
}

\author{
Saurabh Ghosh1, Pawan Gopalakrishnan ${ }^{1}$, Sakshi Satija ${ }^{2}$ \\ ${ }^{1}$ Strategic Research Unit, Reserve Bank of India, Mumbai, India \\ ${ }^{2}$ Ashoka University, Sonepat, India \\ Email: saurabhghosh@rbi.org.in, *pawangopalakrishnan@rbi.org.in, sakshi.satija_phd19@ashoka.edu.in
}

How to cite this paper: Ghosh, S., Gopalakrishnan, P. and Satija, S. (2020) Recapitalization in an Economy with State-Owned Banks-A DSGE Framework. Theoretical Economics Letters, 10, 232-249. https://doi.org/10.4236/tel.2020.101015

Received: January 11, 2020

Accepted: February 25, 2020

Published: February 28, 2020

Copyright (c) 2020 by author(s) and Scientific Research Publishing Inc. This work is licensed under the Creative Commons Attribution International License (CC BY 4.0).

http://creativecommons.org/licenses/by/4.0/

\section{(c) (i) Open Access}

\begin{abstract}
What are the quantitative effects of a government infused bank recapitalization in response to loan defaults? We analyze two different scenarios of government infused recapitalization using a dynamic stochastic general equilibrium (DSGE) model, calibrated to an emerging market economy with state owned banks. The first is an unconditional transfer and the second is an "equity in exchange for transfer" to banks. We show that a government infused recapitalization in response to a negative productivity shock may increase output in the short run. However, there is welfare loss, which is higher in the case of unconditional transfers. Our analysis suggests that bank recapitalization facilitates credit creation, capital formation and growth, especially during a cyclical downturn. There is however a need for appropriate policy vigil to protect the quality of public expenditure in the social sector that matters for welfare in the long run.
\end{abstract}

\section{Keywords}

Bank Recapitalization, Statutory Liquidity Ratio (SLR) Requirements, Emerging Market Economies, Financial Frictions, State Owned Banks

\section{Introduction}

The global financial crisis (2008) underlined the pivotal role of the banking sector in advanced and emerging market economies and also brought to fore some of the limitations of the existing international banking regulations (see BIS Paper No. 60, 2018 [1]). Considering the importance of banks as a shock absorber between the financial and real sector, a host of policy measures were initiated focusing upon improving the quality of banks' balance sheets, thereby providing cushion to these institutions against unexpected shocks. One of the major bank- 
ing sector reform measures included in the Basel III regulation relates to improving the quality and quantity of banks' capital, aimed to make the financial system more resilient, reduce the cost of borrowing, and promote economic growth (see BCBS regulation papers on Basel IIIl, 2010 [2] [3]). Therefore, because of the increased capital requirements under Basel III regulations, and to account for the erosion of capital during GFC defaults, banks have required fresh bouts of recapitalization.

Historically, several large recapitalization measures were undertaken both in advanced and emerging economies during the post-GFC period. For advanced economies, such recapitalization measures were primarily undertaken through issuing debt, preference shares, and/or common equity by the promoters of banks that are seeking recapitalization (Panetta et al. 2009 [4]). However, recapitalizing banks in emerging market economies (EMEs) using the same set of instruments is more challenging mainly because capital markets are emerging, and availability of funds is costly. In addition, in EMEs like India, the government is a major stake holder in many banks that contributes significantly to the overall credit. Given that real economic activity in EMEs and therefore GDP growth have largely been dependent on credit creation by banks due to underdeveloped capital markets, and that large banks are state-owned, recapitalization measures for these banks are typically undertaken by the government.

An increase in regulatory requirement in the face of lack of promoters' capital infusion in EMEs could lead to significant decline in risky investment and an increase in the share of non-risky investments (such as government bonds) in order to achieve the target risk-based capital adequacy requirements. To avoid such a regulatory arbitrage, governments have been facing increasing demand for budgetary allocation to banks' capital for promoting efficient allocation of resources and economic growth.

There is, however, a trade-off, with the government bank recapitalization plan. This could result in rationalization of the government's capital investment and other social expenditures, which might in turn have an adverse impact on the long-run economic growth and welfare. Hence, the objective of this paper is to analyze the mechanics and the offsetting effects of a government induced recapitalization plan in a dynamic stochastic general equilibrium (DSGE) framework. In our model, we assume a state-owned bank dependent economy. We model two different scenarios. In the first, the government makes an unconditional transfer to the state-owned banks to cover their losses due to firm defaults as a result of a negative productivity shock. In the second scenario, the government extends conditional transfers, i.e., the government's equity holding in these banks is linked to the transfers. Therefore, higher transfers would imply a higher share of the government ownership of these banks.

We parametrize our model to the Indian economy, primarily because economic activity in India is still largely dependent on bank credit. For instance, as on 2018, credit from banks contributed to substantial portion of overall credit to the manufacturing sector. In addition, more than $63 \%$ of overall bank credit is 
extended by Public Sector Banks (PSBs). Moreover, Statutory Liquidity Requirements (SLRs) require banks to hold a mandatory portion of their deposits in the form of government securities. ${ }^{1}$ Furthermore, a large portion of the population in India is still dependent on the agriculture for a livelihood. Even though the share of agriculture in overall GDP has been falling, banks are mandated to extend $40 \%$ of their adjusted net credit to priority sectors. ${ }^{2}$ Therefore, even a negative rainfall shock may aggravate the stress in the banking sector because of banks' exposure to agriculture and the risks of negative rainfall shocks. This will have an indirect impact on aggregate demand and output.

India is also committed to abide by the Basel III recommendations in a phased manner. PSBs in the past have received recapitalization from the government. Such recapitalization measures include recapitalization bonds (1994), special budgetary allocation, and market borrowing schemes (e.g., Indradhanush plan, 2015). In October 2017, the government announced recapitalization measures to improve the balance sheets of stressed banks, again through a combination of recapitalization bonds, budgetary support, and market borrowing. Subsequent Union Budgets also proposed funds for recapitalization. ${ }^{3}$ In terms of fiscal costs, these large infusions have reinvigorated the debate on whether such measures would crowd-out other productive spending and thereby adversely impact welfare. This is particularly important in the context of EMEs such as India, which are on a fiscal consolidation path, and the share of capital expenditure is already small in overall expenditures.

Our model findings indicate that government transfers help the banking sector under both unconditional and conditional scenarios in the short-run. In particular, the equity-linked transfer scheme provides some discipline into banks, compared to the unconditional budgetary transfer. As an offsetting effect, however, recapitalization measures crowd-out social sector spending, which we model as utility enhancing government expenditures. This could have an adverse impact on overall welfare. Our analysis broadly suggests that a calibrated approach to address banks' balance-sheet issues by fresh capital injection for immediate credit creation can be given priority. However, there is a requirement for appropriate vigil on government expenditure in the social sector to prevent long run adverse implications on welfare.

The paper is organized as follows. Section 2 describes the structure of our paper and benchmarks it with the existing literature. Section 3 elaborates on the model with calibrations and impulse responses due to negative productivity shocks under both alternative scenarios, i.e., unconditional and conditional gov${ }^{1}$ See Table 46, Sectoral Deployment of Non-Food Credit, RBI Handbook of Statistics on the Indian Economy, 2018 for data on manufacturing and priority sector oustanding credit calculations. [5] ${ }^{2}$ As per the mandate, $40 \%$ of total Adjusted Net Bank Credit (ANBC) or Credit Equivalent Amount of Off-Balance Sheet Exposure (whichever is higher), must be extended towards Total Priority Sector Lending. Of this, $18 \%$ of ANBC must be directed towards agriculture. See the RBI Master Direction on Priority Sector Lending (2018):

https://m.rbi.org.in/Scripts/BS_ViewMasDirections.aspx?id=10497 [6].

${ }^{3}$ See the 2019 Union Budget Speect, https://www.indiabudget.gov.in/budgetspeech.php [7]. 
ernment transfers to banks. Finally, Section 4 concludes by offering some policy insights.

\section{Literature}

Our paper adds to the growing literature on bank recapitalization in presence of credit-defaults in a DSGE framework. Our focus, however, is on understanding the mechanics of bank recapitalization in an economy with state-owned banks. We model the banking sector similar to Gerali et al. (2010) [8] and Gunn and Johri (2018) [9]. Gerali et al. (2010) [8] explicitly model the impact of the balance sheet on the real economy through a DSGE framework. Firms borrow from banks to purchase new capital for future production. ${ }^{4}$ More recently, Gunn and Johri (2018) [9] build a model with banks facing capital sufficiency requirements, to study the impact of news on banks' portfolio. They show that a negative news shock could trigger portfolio adjustments in the presence of capital requirements, creating a tighter credit market which pans into negative outcomes.

Banks in our model also face a friction in the form of Statutory Liquidity Ratio (SLR) requirements, i.e., an exogenous portion of the deposits received in every time period must be held in the form of central government securities. This is similar to Lahiri and Patel (2016) [11] who argue that when the constraints bind, a reduction in the policy rate can end up raising lending spreads causing a contraction, instead of an expansion in the economy.

The novelty of our paper lies in the fact that it attempts to study the impact of bank recapitalization in an economy with financially constrained state-owned banks faced with stressed assets, increased capital requirement, a SLR requirement (as in Lahiri and Patel 2016 [11]), and sectoral credit obligations. In our framework, the government exists passively. They undertake utility enhancing social spending, as in Christiano and Eichenbaum (1992) [12], Ambler and Paquet (1996) [13], and Ghate et al. (2016) [14].

\section{The Model}

In this model, there are five agents: households, final good producing firms, intermediate capital good firms, banks and the Government. Households make deposits in banks, and derive utility from effective consumption and leisure. Effective consumption in this model is a non-separable function of private consumption and utility enhancing government expenditure (see Ghate et al. 2016 [14]). This is analogous to social sector spending. This guarantees that fiscal policy has real labor supply outcomes. Households supply labor to firms and get a share of the firms' profits as dividends. Households also receive a portion of banks' profits in the form of dividends payments, although the Government owns majority stake in these banks. The final goods firms produce the final good ${ }^{4}$ Recently, Banerjee et al. (2018) [10] build and calibrate a monetary DSGE model for India with banks modeled similar to Gerali et al. (2010) [8] to understand why the aggregate demand channel of monetary transmission is weak. 
using labor hired from households, and new capital purchased from the intermediate capital goods sector. The intermediate capital goods sector on the other hand purchases undepreciated capital from the firms producing the final good and refurbish them to produce new capital (see Banerjee et al. 2018 [10], Gunn and Johri 2018 [9], and Gerali et al. 2010 [8] for a setup of the capital goods sector).

Banks receive deposits from households, of which a fixed portion is mandatorily held in the form of government bonds, i.e., SLR. This is analogous to the Basel-III mandate of Liquidity Coverage Requirement (LCR). The remainder share of the deposits is lent to firms to purchase new capital for producing the single final good in the economy. Finally, the government taxes household consumption and wage incomes, borrows by issuing bonds to banks, and undertakes a utility-enhancing expenditure which augments households' utility.

\subsection{Firms}

The economy consists of two sectors on the production side-a final goods producing firm and a capital goods producing firm. The capital goods firm supplies new capital to the final goods firm at a market price in every time period. The final goods firm produces the final good which is consumed by the households and the government, and is the only source of investment in the physical asset.

\subsubsection{Capital Goods Producing Firm}

Our description of the capital goods producing firms is as in Gerali et al. (2010) [8] and Banerjee et al. (2018) [10]. Perfectly competitive firms buy last period's undepreciated capital, $\left(1-\delta_{K}\right) K_{t-1}$-where $\delta_{K}$ is the rate of depreciation of physical capital-at price $Q_{t}$ from the final goods firms and $I_{t}$ units of the final good. The transformation of the final good into new capital is subject to adjustment costs, $S$, such that

$$
S\left(\frac{K_{t}}{K_{t-1}}\right)=\frac{\kappa}{2}\left(\frac{K_{t}}{K_{t-1}}-1\right)^{2},
$$

where $\kappa$ is the adjustment cost parameter. ${ }^{5}$ The new capital is then sold to the final goods firm. The discounted lifetime profit function of the capital goods firm is given by

$$
\max _{\left\{K_{t}\right\}} E_{0} \sum_{t=0}^{\infty} \Omega_{t, t+1}\left[Q_{t}\left\{K_{t}-\left(1-\delta_{K}\right) K_{t-1}\right\}-I_{t}\right],
$$

subject to the following law of motion of capital accumulation

$$
I_{t}=K_{t}-\left(1-\delta_{K}\right) K_{t-1}+K_{t-1} S\left(\frac{K_{t}}{K_{t-1}}\right) .
$$

Note that, $\Omega_{t, t+1}$ is a stochastic discount factor and is given by,

$$
\Omega_{t, t+1}=\beta E_{t}\left[\frac{U^{\prime}\left(C_{t+1}\right)}{U^{\prime}\left(C_{t}\right)}\right] .
$$

${ }^{5}$ This parametrization of adjustment costs is analogous to Neumeyer and Perri (2005) [15]. 
The stochastic discount factor corresponds to the expected returns the representative household gets from one period bonds and $C_{t}$ is the private consumption of the representative household in period $t$. Since we assume that all production activities are owned by the representative household, the discount factor that corresponds to the capital producing firm's optimization problem corresponds to the household's expected returns from one period bonds. The first order condition w.r.t $K_{t}$ is

$$
\begin{aligned}
\left\{K_{t}\right\}: & \Omega_{t, t+1}\left[Q_{t}-1\right]=\Omega_{t, t+1} \frac{\kappa}{2}\left[2\left(\frac{K_{t}}{K_{t-1}}-1\right)\right] \\
& +E_{t} \Omega_{t+1, t+2}\left[\left(1-\delta_{K}\right)\left(Q_{t+1}-1\right)+\frac{\kappa}{2}\left(1-\left(\frac{K_{t+1}}{K_{t}}\right)^{2}\right)\right] .
\end{aligned}
$$

Equation (5) in the steady state yields,

$$
Q=1 \text {. }
$$

\subsubsection{Final Goods Producing Firm}

The representative final good producing firm, at any given time $t$, hires labor $\left(H_{t}\right)$ and uses capital $\left(K_{t-1}\right)$ accumulated in time period $t-1$ to produce final output $Y_{t}$ using a constant returns to scale (CRS) technology, such that

$$
Y_{t}=A_{t} K_{t-1}^{\alpha} H_{t}^{1-\alpha}
$$

where

$$
A_{t} \sim C S S P,
$$

is the exogenous Total Factor Productivity (TFP). In our calibrations, we will assume that $\alpha<0.5$, i.e., firms are labor intensive, to capture a proto-typical agrarian or allied sector in an emerging economy. At period $t$, firm borrows $L_{t}=Q_{t} K_{t}$ from the bank in order to purchase new capital for next period production, and repays previous period loans, $L_{t-1}$, facing an interest rate of $R_{t-1}^{L}$. In this framework, we assume that the firm defaults in its repayments of $L_{t-1}$ to the bank with a probability $p_{t}^{*}$. This default probability is state contingent, i.e., on the realization of the TFP. In other words,

$$
p_{t}^{*}=p^{*} \exp \left(\bar{A}-A_{t}\right) \text {. }
$$

Therefore, if the realized TFP is lower than the average level of TFP, the probability of default is higher. The probability of default therefore is contingent on the state of the economy, and is higher if the state of the economy is "more bad" versus "less bad". Further, we can interpret a negative shock to productivity as a negative rainfall shock. We also assume that these firms receive loans from banks in every time period, irrespective of the nature of the firm. In other words, unlike Mitra (2013) [16], we do not specify a borrowing constraint on the firms in order to disincentivize firms of "low-type" from borrowing. This is because, we are eventually calibrating our model to India, where a large share of its population is engaged in agrarian or allied sectors, and is rainfall dependent. A neg- 
ative monsoon shock can therefore have a systemic effect on the banking sector and on the overall economy.

The representative firm maximizes its discounted life-time profits given by,

$$
\max _{\left\{K_{t}, H_{t}\right\}} E_{0} \sum_{t=0}^{\infty} \Omega_{t, t+1}\left[Y_{t}-W_{t} H_{t}-Q_{t} K_{t}+\left(1-\delta_{K}\right) Q_{t} K_{t-1}+L_{t}-\left(1-p_{t}^{*}\right) R_{t-1}^{L} L_{t-1}\right],
$$

This yields the following first order conditions w.r.t. $K_{t}$ and $H_{t}$

$$
\begin{gathered}
\left\{K_{t}\right\}: E_{t}\left[\alpha \frac{Y_{t+1}}{K_{t}}+\left(1-\delta_{k}\right) Q_{t+1}-\left(1-p_{t+1}^{*}\right) R_{t}^{L} Q_{t}\right]=0 \\
\left\{H_{t}\right\}: E_{t}\left[(1-\alpha) \frac{Y_{t}}{H_{t}}-W_{t}\right]=0
\end{gathered}
$$

In the steady state,

$$
\begin{gathered}
K=\left[\frac{A \alpha}{Q\left[(1-p) R^{L}-\left(1-\delta_{k}\right)\right]}\right]^{\frac{1}{1-\alpha}} H \\
H=\left[\frac{(1-\alpha) A}{w}\right]^{\frac{1}{\alpha}} K
\end{gathered}
$$

\subsection{Households}

The economy is populated by infinitely lived households with a mass normalized to 1 . A stand-in representative household consumes and invests a homogenous good. It also supplies labor and capital to firms. The household derives utility from effective consumption $\left(C_{t}^{*}\right)$ and leisure $\left(1-H_{t}\right)$. The representative household has the following expected discounted lifetime utility

$$
E_{0} \sum_{t=0}^{\infty} \beta^{t} U\left(C_{t}^{*}, H_{t}\right)
$$

where $\beta \in(0,1)$ denotes the households subjective discount factor. We assume that

$$
C_{t}^{*}=C_{t}+\mu G_{t}^{C}, \mu>0
$$

where household consumption $\left(C_{t}\right)$ is augmented by government consumption $\left(G_{t}^{C}\right)$. The parameter $\mu$ captures the weight of public consumption in household utility, where $\mu>0$. Given our specification in Equation (16), $C_{t}$ and $G_{t}^{C}$ are assumed to be perfect substitutes. ${ }^{6}$ The only source of consumption smoothing for the household is that they make bank deposits. Households make deposits $d_{t}$ in state owned banks on which they receive gross interest income $R_{t}^{D}$. They supply labor to firms, and in return receive wages $W_{t}$. They also receive $(1-e)$ proportion of the bank's profit, $\Pi_{t}^{b}$. Therefore, the representative ${ }^{6}$ In an emerging markets context, an example of $G_{t}^{c}$ can be public health or public transportation services. See Barro (1981) [17], Christiano and Eichenbaum (1992) [12], Ambler and Paquet (1996) [13], and Ghate et al. (2016) [14]. Households in a typical emerging economy, rely heavily on such public services. 
household maximizes the following discounted life-time utility function

$$
\max _{\left\{C_{t}, H_{t}, d_{t}\right\}} E_{0} \sum_{t=0}^{\infty} \beta^{t}\left[\ln \left(C_{t}+\mu G_{t}^{C}\right)+\ln \left(1-H_{t}\right)\right],
$$

subject to,

$$
\left(1+\tau_{C}\right) C_{t}+d_{t} \leq\left(1-\tau_{W}\right) W_{t} H_{t}+R_{t-1}^{D} d_{t-1}+(1-e) \Pi_{t}^{b},
$$

where $\tau_{C}$ is the tax on consumption, and $\tau_{W}$ is the tax on labor income. First order conditions yield

$$
\begin{gathered}
\frac{1}{C_{t}^{*}}=\beta E_{t}\left[\frac{R_{t}^{D}}{C_{t+1}^{*}}\right], \\
\left(\frac{C_{t}^{*}}{W_{t}}\right)\left(\frac{1+\tau_{C}}{1-\tau_{W}}\right)=1-H_{t}
\end{gathered}
$$

where (18) is the Euler equation, and (19) is the standard marginal rate of substitution between effective consumption and leisure.

In the steady state,

$$
R^{D}=\frac{1}{\beta},
$$

that is, in the steady state, the deposit rate is the inverse of the discount factor. Finally,

$$
\left(\frac{C^{*}}{W}\right)\left(\frac{1+\tau_{C}}{1-\tau_{W}}\right)=1-H .
$$

\subsection{Banks}

Banks are state-owned, of unit mass. A portion $e$ of a representative bank's profits in every time period $t$, goes to the government, and the rest goes to households. The bank receives deposits $d_{t}$ from the household, a fraction $\Phi$ of which is held as government bonds. On these government bonds, the bank earns a pre-announced gross interest rate of $R_{t}^{G}$ at a given $t$. The remaining proportion $(1-\Phi)$ of total deposits is used for lending activity to the final goods producing firms so that they can purchase new capital from the intermediate capital producing sector. The lending rate is $R_{t}^{L}$ at a given time period $t$. The bank also incurs a monitoring cost $\gamma\left(L_{t}\right)$ to reduce the default risk. In case of a default, banks receive a transfer $p_{t}^{*} R_{t-1}^{L} L_{t-1}$ from the government for the loss incurred due to non-repayment by firms. While, theoretically it is interesting to model banks receiving recapitalization based on their efforts in identifying bad loans, and banks receiving recapitalization in India is also linked to their performances, we abstain from these "moral hazard issues" in our current framework. This is because, in some of the EMEs, including India, banks extend substantial portion of their credit to the agricultural sector. Though the share of agriculture in the overall GDP is declining in India, it continues to employ con- 
siderable share of the overall labor force and therefore plays an important role in aggregate demand, and consequently in aggregate welfare. Given the agricultural dependence of aggregate demand, and state-ownership of banks, we assume in a simplified framework, that the general government waivers off a portion of the bank's "bad-loans" or infuses capital against equity in the bank, when faced with a negative productivity shock, e.g., a bad monsoon shock.

The following is the optimization problem of a representative state owned bank.

$$
\begin{aligned}
\Pi_{t}^{b}= & E_{0} \sum_{t=0}^{\infty} \Omega_{t, t+1}\left[d_{t}-R_{t-1}^{D} d_{t-1}-L_{t}+\left(1-p_{t}^{*}\right) R_{t-1}^{L} L_{t-1}\right. \\
& \left.-\Phi d_{t}+R_{t-1}^{G} \Phi d_{t-1}-\gamma\left(L_{t}\right)+p_{t}^{*} R_{t-1}^{L} L_{t-1}\right]
\end{aligned}
$$

where,

$$
\begin{gathered}
L_{t} \leq(1-\Phi) d_{t} \\
\gamma\left(L_{t}\right)=\gamma L_{t}^{\sigma}, \sigma \geq 1 .
\end{gathered}
$$

This yields the first order condition

$$
R_{t}^{D}=(1-\Phi) R_{t}^{L}+\Phi R_{t}^{G}-\frac{1}{\beta} \gamma \sigma(1-\Phi)^{\sigma} d_{t}^{\sigma-1}
$$

Assuming $\sigma=1$ for analytical tractability, in the steady state,

$$
R^{L}=\frac{1-\beta \Phi R^{G}+\gamma(1-\Phi)}{(1-\Phi) \beta} .
$$

Equation (26) is the No-Arbitrage condition which governs the relationship between the steady deposit rate, the gross returns on government bonds, and the lending rate. We can show that as $\Phi$ increases, $R^{L}$, i.e., the steady state gross lending rate decreases. At the same time, as $R^{G}$ increases, $R^{L}$ decreases. This could happen because sovereign bonds in domestic currency, are generally considered risk free, and therefore are assigned zero risk weight. A bank, faced with a binding capital-to-risk-weighted asset ratio (CRAR), is therefore likely to invest more in zero risk-weighted assets rather than investing in risky ventures. This regulatory arbitrage could result in dampened capital formation, impacting long-term economic growth and welfare. To avoid such a regulatory arbitrage, the government faces increasing demand for budgetary allocation towards the representative bank's capital, for promoting efficient capital formation and consequently economic growth.

\subsection{Government}

The government exists passively in this model. It exogenously imposes taxes on consumption $\left(\tau_{C}\right)$ and wage income $\left(\tau_{W}\right)$ and receives a proportion $e$ of bank's profits. An indirect tax on consumption, $\tau_{C}$, is included in view of India's large dependence on indirect taxes, introduction of GST, and to give additional flexibility for the purpose of calibrating our model. The government also 
extends transfers to banks to compensate them for losses incurred due to non-repayment by firms, i.e., bad loans. The following is the budget constraint faced by the government,

$$
G_{t}^{C}=\tau_{C} C_{t}+\tau_{W} W_{t} H_{t}-\Phi R_{t-1}^{L} d_{t-1}+\Phi d_{t}+e \Pi_{t}^{b}-p R_{t-1}^{L} L_{t-1}
$$

One of the simplifying assumptions of our model is that the government does not optimize fiscal policy. It imposes an exogenous taxes, and SLR on banks which is mainly because of the macro-prudential considerations, that helps finance government borrowing. The government waives off a portion of bank's bad loans unconditionally or transfers capital against equity mainly to smooth the impact of a negative productivity shock and such transfers crowd out government's utility enhancing expenditure $\left(G_{t}^{C}\right)$. In our model, the government budget constraint (GBC) is therefore balanced using $G_{t}^{C}$ therefore taking care of Ricardian Equivalence.

\subsection{The Non-Stochastic Steady State System}

The following summarizes the non-stochastic steady state of the system ${ }^{7}$

$$
\begin{aligned}
& \left(\frac{C^{*}}{W}\right)\left(\frac{1+\tau_{C}}{1-\tau_{W}}\right)=1-H \\
& R^{D}=\frac{1}{\beta} \\
& \left(1+\tau_{C}\right) C+d=\left(1-\tau_{W}\right) W H+R^{D} d+(1-e) \Pi^{b} \\
& Q=1 \\
& K=\left[\frac{A \alpha}{Q\left[(1-p) R^{L}-\left(1-\delta_{k}\right)\right]}\right]^{\frac{1}{1-\alpha}} G^{P} H \\
& H=\left[\frac{(1-\alpha) A\left(G^{P}\right)^{1-\alpha}}{w}\right]^{\frac{1}{\alpha}} K \\
& L=Q K \\
& Y=A K^{\alpha}\left(G^{P} H\right)^{1-\alpha} \\
& R^{L}=\frac{1-\beta \Phi R^{G}+\gamma(1-\Phi)}{(1-\Phi) \beta} \\
& \Pi^{b}=\gamma(1-\Phi)\left(\frac{1}{\beta}-1\right) d \\
& L=(1-\Phi) d \\
& G^{C}=\tau_{C} C+\tau_{W} W H-\Phi R^{G} d+\Phi d+e \Pi^{b}-p R^{L} L
\end{aligned}
$$

${ }^{7}$ See Appendix for derivations. 


\subsection{Numerical Simulations}

\section{Parameter Values}

We fix the tax rate on consumption $\tau_{c}=0.12$ and $\alpha=0.35$ from Ghate et al. (2016) [14]. We normalize average Total Factor Productivity, $A=1$. Given that India has a very narrow income tax base and depends more on generating revenue from indirect taxation, we allow for a low income tax at $\tau_{w}=0.01$ (see Poirson 2006 [18]). The depreciation rate of capital $\delta_{k}=0.1$, which matches approximately 10\% of annual rate of depreciation (Gabriel et al. 2012 [19]). The gross rate of return on government bonds $R^{G}$ is equal to 1.02 which roughly matches the long run average gross real rate of return on 91-day treasury bill rates in India. The mandatory proportion of deposits that are to be held in the form of government bonds $\Phi$, is equals to 0.2 , which roughly matches the Statutory Liquidity Rates in India. The household's discount rate $\beta$ is fixed at 0.98 (see Gabriel et al. 2012 [19]). Monitoring cost parameters $\gamma$ and $\sigma$ are arbitrarily fixed at values $>1$ and $\geq 1$ respectively. The capital adjustment cost $\kappa$ is arbitrarily chosen to be equal to 0.2 . Table 1 summarizes our choice of deep parameters in our model.

\subsection{Impulse Response Functions}

In this section, we will analyze the impact of a one period negative shock to productivity that affects the probability of default, $p_{t}^{*}$. In particular, we assume that poor monsoon operates as a negative productivity shock, and follows a CSSP process, i.e. ${ }^{8}$,

$$
p_{t}^{*}=p^{*} \exp \left(\bar{A}-A_{t}\right), \text { where } A_{t} \sim \operatorname{CSSP} .
$$

Table 1. Parameters for Calibration.

\begin{tabular}{ccc}
\hline Parameters & Values & Source \\
\hline$\alpha$ & 0.35 & Ghate et al. (2016) \\
$\beta$ & 0.98 & Gabriel et al. (2012) \\
$\gamma$ & $>1$ & Arbitrary \\
$\sigma$ & 1 & Arbitrary \\
$\kappa$ & 0.2 & Arbitrary \\
$\tau_{c}$ & 0.12 & Ghate et al. $(2016)$ \\
$\tau_{w}$ & 0.01 & Poisron (2001) \\
$\mu$ & 0.5 & Arbitrary \\
$\delta_{k}$ & 0.1 & Data \\
$R^{G}$ & 1.02 & Data \\
$\Phi$ & 0.2 & Data \\
$p^{*}, A$ & Exogenous & Authors
\end{tabular}

${ }^{8}$ Our motivation for this specification is to capture the borrower's inability to repay loans on account of crop failures, which culminates into large decline in aggregate demand. 
TFP $A_{t}$ in turn is modeled as follows

$$
A_{t}=\bar{A} \exp \left(\hat{A}_{t}\right),
$$

where

$$
\hat{A}_{t}=\rho_{A} \hat{A}_{t-1}+\varepsilon_{A t} \text {, and } \varepsilon_{A t} \sim N\left(0, \sigma_{A}^{2}\right) .
$$

A negative productivity shock will correspond to a negative draw of $\varepsilon_{A t}$ from $N\left(0, \sigma_{A}^{2}\right)$.

This implies, if $A_{t}<A, p_{t}^{*}>p^{*}$, i.e., the probability of default increases, in comparison to the steady state.

\section{Baseline Case - Unconditional Transfers}

Suppose the government makes an unconditional transfer, i.e., a loan waiver. In this case, the government compensates banks for all the loss due to non-repayment by the borrowing firms. In other words, the transfers made by the government to the representative bank is

$$
p_{t}^{*} R_{t-1}^{L} L_{t-1} .
$$

This is equivalent to an ex-post transfer extended to banks, which effectively lowers the borrowing costs of firms due to the absence of provision requirements. Such a recapitalization measure helps insulate banks that are affected by loan defaults on account of negative and exogenous shocks.

Now, suppose there is a one period productivity shock. Figure 1 shows the impulse response functions of various macroeconomic variables. A negative productivity shock leads to an increase in the probability of default, and impacts the final good firms compelling them to default. However, the government bails out banks through their transfer schemes. This, from the GBC, impacts utility enhancing government expenditure, and therefore adversely impacts household welfare. In an attempt to maintain effective consumption, $C^{*}$, the household supplies more labor. The firm, in face of an increase in labor supply, borrows from banks in order to purchase capital. Therefore, an increased labor supply coupled with bank recapitalization, resulting increased demand for loans helps in maintaining/marginally increasing output even in a situation of an adverse productivity shock. However, private consumption drops because current wages fall, and interest rates increase, thereby dis-incentivizing current private consumption. On the whole, this results in a welfare loss for households.

The government transfers help in uninterrupted credit disbursement by banks that support capital formation and help in maintaining output. However, overall welfare is adversely impacted because of fall in government utility enhancing expenditure, increased labour supply and increased deposit demand, and decline in dividend from bank profits, thereby further reducing current private consumption.

\subsection{Conditional Transfers}

Now suppose, the government imposes a rule that it will transfer $p_{t}^{*} R_{t}^{L} L_{t-1}$ to 

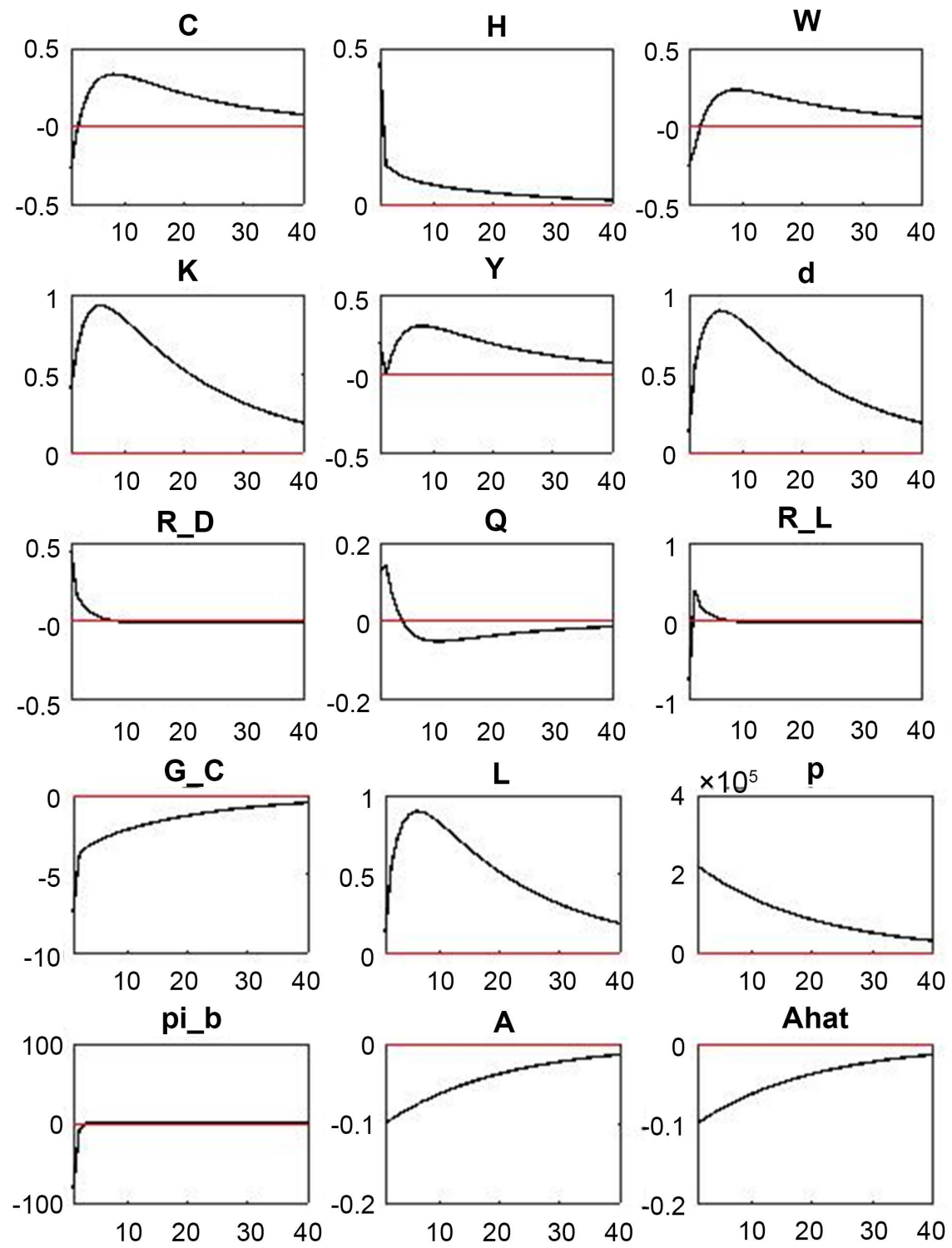

Figure 1. One period negative productivity shock.

banks in the instance of firms defaulting, but in return, insists on a higher equity holding of banks, a case similar to capital infusion in banks. In this case, we assume

$$
e=\underline{e}+\varpi \cdot p^{*}, \varpi>0
$$

i.e., a higher $p^{*}$ implies higher $e$, or in other words, a higher share of the representative bank's profits accrues to the government. As a consequence, the residual bank profits accruing to households are lower.

Figure 2 shows the impulse response functions of a one period productivity shock in the case where the government demands higher equity holding in bank's profits in return of higher transfers being made, on account of higher $p^{*}$. As before, the default probability of the firm is tied to the productivity business cycle such that,

$$
p_{t}^{*}=p^{*} \exp \left(\bar{A}-A_{t}\right)
$$



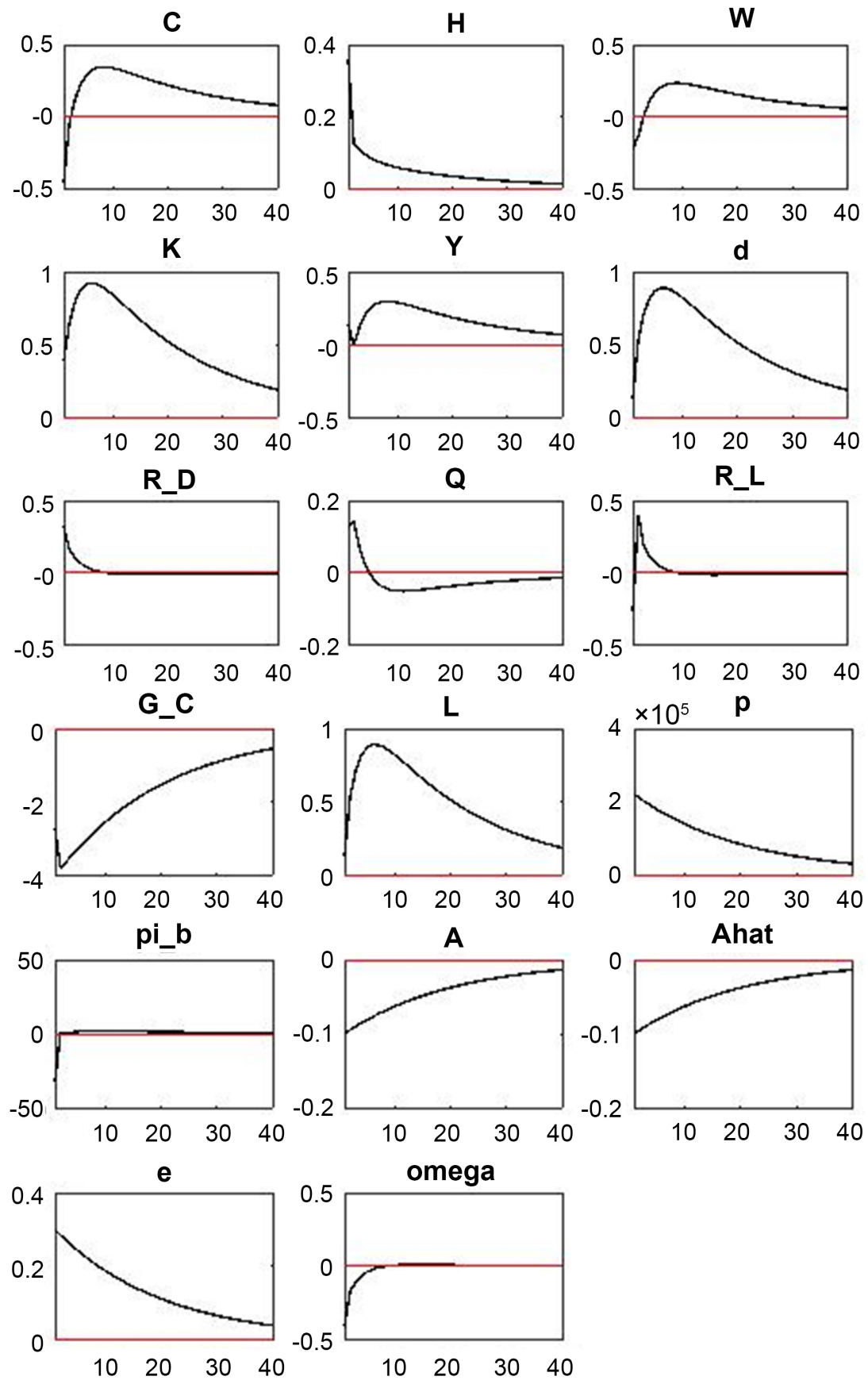

Figure 2. One period productivity shock: endogenous equity.

It is observed that the impact of a negative productivity shock on the real economy remains qualitatively unchanged. However, the welfare loss is lesser now as compared to the unconditional transfer case. This is mainly so because now the government holds a higher stake in banks and absorbs the decline in $\pi^{b}$. Therefore the decline in private consumption through the income channel is weakened compared to the unconditional case. Consequently, in this scenario with equity transfers, the increase labour supply and decline in wages are also weakened culminating to a net positive effect on the income tax collection (as 
compared with unconditional transfer). On the net $G_{t}^{C}$ declines by less, compared to the case of unconditional transfers. As a result, the overall decline in household welfare is smaller compared to the case of unconditional transfers.

\section{Conclusion and Policy Implications}

The goal of this paper is to understand the impact of government's attempt to strengthen/recapitalize banks. To this end, we analyze a DSGE model with five agents: households, final good firms, capital good firms, banks and the government. In our model with state-owned banks, the government makes an unconditional transfer to the banks for the loss due to non-repayment by the borrowing firms. Impulse responses for a negative shock to productivity show that there are large welfare costs due to lower public utility spending, lower private consumption and wages. However, these transfers reduce the cost of capital thereby enhancing capital formation. As a result, this helps to smooth output and employment even in the face of a negative productivity shock.

We then consider an alternate scenario of conditional transfers, where the government allocates capital in exchange of banks' equity. Assuming equity to be one-to-one linked with the transfers, the impulse response functions of a negative productivity shock show similar qualitative impacts on the real economy, but with a relatively smaller fall in public utility spending as compared to the unconditional case. This suggests equity transfers could be a better way of implementing a recapitalization program.

Our analysis suggests that bank recapitalization is a welcome move to kick-start credit creation, capital formation and growth. However, there is a need for appropriate policy vigil to protect the quality of public expenditure in the social sector that matters for welfare.

\section{Acknowledgements}

We thank Amartya Lahiri, Chetan Subramaniam, Abhishek Ranjan, Debojyoti Mazumder, and seminar participants at RBI-CAFRAL-IIMB conference. We would also like to thank the editor and the referee for their valuable comments. Views expressed by the authors are strictly personal and not necessarily of the institution that they belong to.

\section{Conflicts of Interest}

The authors declare no conflicts of interest regarding the publication of this paper.

\section{References}

[1] Committee on the Global Financial System (2018) Structural Changes in Banking after the Crisis. Bank for International Settlements, Switzerland, Paper No. 60.

[2] Basel Committee on Banking Supervision (2010) Basel III: A Global Regulatory Framework for More Resilient Banks and Banking Systems. Bank for International 
Settlements, Switzerland.

[3] Basel Committee on Banking Supervision (2010) Basel III: International Framework for Liquidity Risk Measurement, Standards and Monitoring. Bank for International Settlements, Switzerland.

[4] Fabio, P., Faeh, T., Grande, G., Ho, C., King, M., Levy, A., Signoretti, F.M., Taboga, M. and Zaghini, A. (2009) An Assessment of Financial Sector Rescue Programmes. BIS Paper No. 48.

[5] RBI Handbook of Statistics of the Indian Economy, Table 46 (2018)

https://www.rbi.org.in/Scripts/PublicationsView.aspx?id=18511

[6] RBI Master Direction for Priority Sector Lending (2018) https://m.rbi.org.in/Scripts/BS_ViewMasDirections.aspx?id=10497

[7] Union Budget Speech (2019) https://www.indiabudget.gov.in/budgetspeech.php

[8] Andrea, G., Neri, S., Sessa, L. and Signoretti, F.M. (2010) Credit and Banking in a DSGE Model of the Euro Area. Journal of Money, Credit, and Banking, 42, 107-141. https://doi.org/10.1111/j.1538-4616.2010.00331.x

[9] Gunn, C.M. and Johri, A. (2018) Financial News, Banks, and Business Cycles. Macroeconomic Dynamics, 22, 173-198. https://doi.org/10.1017/S1365100516000134

[10] Shesadri, B., Basu, P., Ghate, C., Gopalakrishnan, P. and Gupta, S. (2018) A Monetary Business Cycle Model for India. CEGAP Working Papers, Durham University Business School, Durham.

[11] Lahiri, A. and Patel, U. (2016) Challenges of Effective Monetary Policy in Emerging Economies. RBI Working Paper Series. https://doi.org/10.1007/978-81-322-2840-0_2

[12] Christiano, L.J. and Eichenbaum, M. (1992) Current Real Business Cycle Theories and Aggregate Labor Market Fluctuations. American Economic Review, 82, 430-450.

[13] Ambler, S. and Paquet, A. (1996) Fiscal Spending Shocks, Endogenous Government Spending, and Real Business Cycles. Journal of Economic Dynamics and Control, 20, 237-256. https://doi.org/10.1016/0165-1889(94)00850-X

[14] Chetan, G., Gopalakrishnan, P. and Tarafdar, S. (2016) Fiscal Policy in an Emerging Market Business Cycle Model. Journal of Economic Asymmetries, 14, 52-77. https://doi.org/10.1016/j.jeca.2016.07.004

[15] Neumeyer, P.A. and Perri, F. (2005) Business Cycles in Emerging Economies: The Role If Interest Rates. Journal of Monetary Economics, 52, 345-380. https://doi.org/10.1016/j.jmoneco.2004.04.011

[16] Shalini, M. (2013) Informality, Financial Development and Macroeconomic Volatility. Economics Letters, 120, 454-457. https://doi.org/10.1016/j.econlet.2013.05.028

[17] Barro, R.J. (1981) Output Effects of Government Purchases. Journal of Political Economy, 89, 1086-1121. https://doi.org/10.1086/261024

[18] Poirson, H. (2006) The Tax System in India: Could Reform Spur Growth? IMF Working Paper. https://doi.org/10.5089/9781451863536.001

[19] Vasco, G., Levine, P., Pearlman, J. and Yang, B. (2012) An Estimated DSGE Model of the Indian Economy. In: Ghate, C., Ed., The Oxford Handbook of the Indian Economy, Oxford University Press, Oxford. 


\section{Technical Appendix}

Derivation of the closed form solutions for the baseline model

From $\{35\}$ and $\{32\}$ respectively, we have

$$
\begin{gathered}
Y=\left[A\left(\frac{K}{Y}\right)^{\alpha}\right]^{\frac{1}{1-\alpha}} H \\
\frac{K}{Y}=\frac{\alpha}{(1-p) R^{L}-\left(1-\delta_{K}\right)}
\end{gathered}
$$

Substituting for $\frac{K}{Y}$, we get

$$
\begin{gathered}
Y=\left\{A\left[\frac{\alpha}{(1-p) R^{L}-\left(1-\delta_{K}\right)}\right]^{\alpha}\right\}^{\frac{1}{1-\alpha}} H \\
\Rightarrow Y=\kappa_{6} H
\end{gathered}
$$

Now, Manipulating $\{28\}$, we get:

$$
H=\frac{1}{1+\frac{\left(1+\tau_{C}\right)\left(\frac{C}{Y}+\mu \frac{G^{C}}{Y}\right)}{\left(1-\tau_{W}\right)(1-\alpha)}}
$$

Next, Dividing both sides of the consumer's budget constraint $\{30\}$ by $Y$ and rearranging, we get

$$
\begin{aligned}
& \left(1+\tau_{C}\right) \frac{C}{Y}=\left(1-\tau_{W}\right)(1-\alpha)+\left[\left(\frac{1}{\beta}-1\right)+\left(\frac{1}{\beta}-1\right)(1-e) \gamma(1-\Phi)\right] \frac{d}{Y} \\
& \Rightarrow \frac{C}{Y}=\frac{\left(1-\tau_{W}\right)(1-\alpha)+\left[\left(\frac{1}{\beta}-1\right)+\left(\frac{1}{\beta}-1\right)(1-e) \gamma(1-\Phi)\right] \frac{d}{Y}}{1+\tau_{C}}=\kappa_{5}
\end{aligned}
$$

Similarly, dividing both sides of the government's budget constraint $\{39\}$ by $Y$, we get

$$
\begin{gathered}
\frac{G^{C}}{Y}=\tau_{C} \frac{C}{Y}+\tau_{W}(1-\alpha)+\left[\operatorname{er}(1-\Phi)\left(\frac{1}{\beta}-1\right)-\left(R^{G}-1\right) \Phi-p R^{L}(1-\Phi)\right] \frac{d}{Y} \\
\Rightarrow \frac{G^{C}}{Y}=\tau_{C} \kappa_{5}+\tau_{W}(1-\alpha)+\kappa_{3}
\end{gathered}
$$

where,

$$
\begin{gathered}
\frac{d}{Y}=\frac{1}{1-\Phi}\left[\frac{\alpha}{(1-p) R^{L}-\left(1-\delta_{K}\right)}\right]=\kappa_{2} \\
\kappa_{3}=\left[\operatorname{er}(1-\Phi)\left(\frac{1}{\beta}-1\right)-\left(R^{G}-1\right) \Phi-p R^{L}(1-\Phi)\right] \kappa_{2}
\end{gathered}
$$

Substituting $\{46\}$ and $\{47\}$ into $\{45\}$ 


$$
H=\frac{1}{1+\frac{1+\tau_{C}}{\left(1-\tau_{W}\right)(1-\alpha)}\left\{\kappa_{5}+\mu\left[\tau_{C} \kappa_{5}+\tau_{W}(1-\alpha)+\kappa_{3}\right]\right\}}
$$

Solving $\{44\}$ and $\{48\}$ simultaneously

$$
\begin{gathered}
H=\frac{\left(1-\tau_{W}\right)(1-\alpha) \kappa_{6}}{\kappa_{6}\left\{\left(1-\tau_{W}\right)(1-\alpha)+\left(1+\tau_{C}\right)\left[\kappa_{5}+\mu \tau_{C} \kappa_{5}+\mu \tau_{W}(1-\alpha)+\mu \kappa_{3}\right]\right\}}=\kappa_{7} \\
Y=\kappa_{6} \kappa_{7} \\
K=\left[\frac{\alpha}{(1-p) R^{L}-\left(1-\delta_{K}\right)}\right] \kappa_{6} \kappa_{7} \\
d=\frac{1}{1-\Phi}\left[\frac{\alpha}{(1-p) R^{L}-\left(1-\delta_{K}\right)}\right] \kappa_{6} \kappa_{7} \\
\Pi^{b}=\gamma\left(\frac{1}{\beta}-1\right)\left[\frac{\alpha}{(1-p) R^{L}-\left(1-\delta_{K}\right)}\right] \kappa_{6} \kappa_{7} \\
G^{C}=\tau_{C} C+\tau_{W}(1-\alpha) \kappa_{6} \kappa_{7}+\kappa_{3} \kappa_{6} \kappa_{7}
\end{gathered}
$$

